\title{
Post-fledging survival of Adélie penguins at multiple colonies: chicks raised on fish do well
}

\author{
David G. Ainley ${ }^{1, *}$, Katie M. Dugger ${ }^{2}$, Mario La Mesa ${ }^{3}$, Grant Ballard ${ }^{4}$, \\ Kerry J. Barton ${ }^{5}$, Scott Jennings ${ }^{2,4,6}$, Brian J. Karl ${ }^{5}$, Amelie Lescroël ${ }^{4}$, \\ Phil O'B. Lyver ${ }^{5}$, Annie Schmidtt ${ }^{4}$, Peter Wilson ${ }^{5}$ \\ ${ }^{1}$ H. T. Harvey \& Associates Ecological Consultants, Los Gatos, CA 95032, USA \\ ${ }^{2}$ US Geological Survey, Oregon Cooperative Fish and Wildlife Research Unit, Department of Fisheries and Wildlife, \\ Oregon State University, Corvallis, OR 97331, USA \\ ${ }^{3}$ ISMAR-CNR, Istituto di Scienze Marine, UOS di Ancona, 60125 Ancona, Italy \\ ${ }^{4}$ Point Blue Conservation Science, Petaluma, CA 94954, USA \\ ${ }^{5}$ Landcare Research, Lincoln 7640, New Zealand \\ ${ }^{6}$ Present address: ACR, Cypress Grove Research Center, Marshall, CA 94940, USA
}

\begin{abstract}
We assessed whether the mass of Adélie penguin Pygoscelis adeliae fledglings at 3 colonies of markedly disparate size on Ross Island, Ross Sea, correlated with their eventual return as subadults. We compared our results with those from Anvers Island, Bellingshausen Sea. Colony sizes at Ross Island have been increasing, contrary to decreasing size at Anvers Island. At Ross Island, during the month prior to fledging, chick diet consisted equally of energy-dense Antarctic silverfish Pleuragramma antarctica and less-caloric crystal krill Euphausia crystallorophias, while at Anvers Island the diet was principally Antarctic krill E. superba. At Ross Island, the mass of fledglings who subsequently returned (mean \pm SE: $3.4 \pm 0.0411 \mathrm{~kg}$ ) exceeded that of those not seen again $(3.2 \pm 0.0251 \mathrm{~kg})$, compared to Anvers Island ( $3.2 \mathrm{vs} .3 .0 \mathrm{~kg}$, respectively). At Ross Island, fledging mass was inversely related to colony size and, at the largest colony, fledging mass decreased as the colony grew. Average mass of returnees at the largest colony was less than the mass at Anvers Island for those fledglings that did not return. The mean proportion of fish in the chicks' diet decreased at the largest Ross Island colony over time, as did fledging mass. We hypothesize that intraspecific competition increased along with colony size, decreasing the availability of fish. We further hypothesize that at the large Ross Island colony, post-fledging penguins must be finding adequate prey, and more energy-dense fish, just outside the colony's foraging area to explain opposing trends in colony trajectories.
\end{abstract}

KEY WORDS: Adélie penguin · Antarctic silverfish · Anvers Island · Central-place foraging · Ross Island $\cdot$ Intraspecific trophic competition

\section{INTRODUCTION}

Most avian species that raise altricial young are also central-place foragers (Orians \& Pearson 1979), regardless of whether they feed within their respective territory (i.e. many land birds) or in a common area separate from the breeding site (i.e. seabirds).

\footnotetext{
${ }^{*}$ Corresponding author: dainley@penguinscience.com
}

For colonial birds, the size of the common foraging area correlates positively with colony size (Storer 1952, Ashmole 1963, Diamond 1978, Furness \& Birkhead 1984, Brown \& Brown 1996, Wakefield et al. 2013). The reproductive goal of these birds is to provide sufficient food to their young in a constrained timeframe so that fledglings leave in good

() The authors 2018. Open Access under Creative Commons by Attribution Licence. Use, distribution and reproduction are unrestricted. Authors and original publication must be credited. 
physical condition with a high chance of subsequent survival (see Maness \& Anderson 2013, Remeš \& Matysioková 2016, Naef-Daenzer \& Grüebler 2016). The amount and quality of food provided has demographic consequences, as nestling body condition carries over to affect subsequent post-fledging survival (e.g. Schmutz 1993, Cam et al. 2003, Vitz \& Rodewald 2011, Arizaga et al. 2015, Jones et al. 2017, Perrig et al. 2017). Thus, fledgling mass must reach a level that provides enough of an energetic buffer for post-fledging individuals as they learn to forage (Lack 1968, Sagar \& Horning 1998). This is perhaps especially critical for seabirds who occupy a spatially and temporally varying 'preyscape', i.e. the availability of prey varying by species composition, depth, horizontal distribution, and size/spacing of schools (for actual measurement, see Ainley et al. 2015, Ford et al. 2015, Saenz et al. 2018, and 'Discussion'). Among central-place foragers, foraging efficiency (i.e. the rate of net energy gain, calculated as the ratio of total energy gained to energy expended; Ydenberg et al. 1994) is expected to be at a premium. Parent seabirds can feed chicks more efficiently by increasing food load size, feeding frequency and/or food quality, using as little energy as possible (e.g. Salihoglu et al. 2001, Chapman et al. 2010, 2011). Parental effort and foraging efficiency vary as a function of qualities of the preyscape, which in turn is a function of environmental factors (e.g. Schreiber 2002, Shealer 2002), as well as intraand interspecific competition (Furness \& Birkhead 1984, Ainley et al. 2003a, 2006, 2015, Davoren \& Montevecchi 2003a) and various intrinsic factors like age and individual quality (e.g. Tveraa et al. 1998, Ballard et al. 2010a, Lescroël et al. 2010).

Among several penguin species, chicks fledging at heavier mass have a higher probability of survival during their initial period at sea (e.g. little penguin Eudytula minor, Reilly \& Cullen 1982; yellow-eyed penguin Megadyptes antipodes, McClung et al. 2004; Adélie penguin Pygoscelis adeliae, Salihoglu et al. 2001, Chapman et al. 2011; and king penguin Aptenodytes patagonica, Olsson 1997, Saraux et al. 2011). However, all of these studies indicating carryover effects from the nestling period on subsequent survival of young have resulted from efforts at one colony within the broad zoogeographic range of each species, and thus, universality of the patterns can only be surmised. For the Adélie penguin, higher quality diet, and specifically, the relative proportion of fish in the diet, appear to be related to higher mass at fledging (Chapman et al. 2011), structural size (e.g. mass, wing length, bill length; Whitehead et al.
2015), and sex-based differences in growth rates (Jennings et al. 2016). Penguin fledging mass varies interannually, presumably due to variation in prey availability (Williams \& Croxall 1991, Olsson 1997, Hinke et al. 2007, Chapman et al. 2010, 2011, Saraux et al. 2011, Waluda et al. 2012, Whitehead et al. 2015), a pattern also evident in other seabirds (e.g. Davoren \& Montevecchi 2003a).

In the present study, we investigated the relationship between body mass at fledging and subsequent return rates at 3 Adélie penguin colonies of differing size on Ross Island, Ross Sea, and compared our results with those from a fourth colony studied elsewhere. Interannual variation in fledging condition (mass vs. body size) was previously investigated at these colonies (Whitehead et al. 2015), but the impact of chick mass at fledging on subsequent return rates (indexing survival) was not evaluated. Herein, we extended that study to look at return rates (proportion of cohort that returns and is observed $\geq 1$ time by age 5), and also related fledging mass to the relative prevalence of fish and krill in the chicks' diet. Finally, we compared our results to those of Chapman et al. (2010, 2011) who investigated fledging mass, diet, and subsequent return rates at Anvers Island, off the western Antarctic Peninsula, where the preyscape differs from the waters around Ross Island in several ways. At Anvers Island, the energy-dense Antarctic silverfish Pleuragramma antarctica was scarce and the diet was composed mostly of Antarctic krill Euphausia superba. This contrasts with waters off Ross Island where silverfish is an important part of the diet, along with crystal krill E. crystallorophias (Ainley et al. 2003b). Furthermore, at Ross Island, colonies were large enough to negatively affect prey availability, which in turn affected foraging effort as well as fledging mass through interference and consumptive competition (Ainley et al. 2004, 2006, 2015, Dugger et al. 2014), whereas at Anvers Island the colony was too small to exhibit such an effect (Cimino et al. 2016). Finally, 2 of the Ross Island colonies were increasing rapidly in size (Lyver et al. 2014) but those of Anvers Island exhibited the opposite trend (Schofield et al. 2010). This raises the question of whether fledging mass and subsequent survival and recruitment of offspring play a role in the disparate population trends, and whether diet may be a mechanism for this effect. Indeed, the modeling of Sailley et al. (2013) pointed to a lack of fish as critical to the Anvers Island colony trajectory. Contrasting the 2 study areas may help elucidate generalities in the relationship of diet, fledging mass and return rates in Adélie penguins. 


\section{MATERIALS AND METHODS}

\section{Study area}

We initiated a long-term study of demography and foraging ecology of Adélie penguins during the 19961997 breeding season (hereafter, seasons identified by initial year) at 3 adjacent colonies on Ross Island and one at Beaufort Island in the southern Ross Sea (Fig. 1). Over the study duration (1996 to 2016), these colonies changed in size as follows: Cape Royds, the smallest, decreased from 4000 to 2300 breeding pairs (see Dugger et al. 2014 for details regarding negative 5 yr effect of a large iceberg on Adélie penguin reproduction); Cape Bird increased from 35000 to 75000 pairs; Beaufort Island increased 35000 to 70000 pairs; and Cape Crozier, one of the 6 largest Adélie penguin colonies in the world (Lynch \& LaRue 2014), increased from 118000 to 305000 pairs. Since Beaufort Island was difficult to access regularly, intensive data collection comparable to the other 3 colonies was not possible (for further information see Lyver et al. 2014, their Fig. 2; Antarctica New Zealand unpubl. data, www.landcareresearch.co.nz/ resources/data/adelie-census-data).

\section{Chick banding and measurements}

Penguin chicks were corralled in pens and banded on the left flipper with an individually numbered stainless steel flipper band (see Dugger et al. 2006) annually at all 3 Ross Island colonies beginning in 1996. Banding occurred 5 to 6 wk post-peak hatching and just before fledging. Chick mass (g) was obtained on a subset of chicks at the time of banding for 8 seasons at Cape Royds, and 3 seasons each at Cape Crozier and Cape Bird (Table 1). At Royds and Crozier, we did not band obviously small chicks (as judged by eye, or whether or not their flipper could retain a band) under the assumption that they would die before fledging. Upon review, those chicks tended to be $<2000 \mathrm{~g}$. At Cape Bird, collaborating researchers used $<2500 \mathrm{~g}$ as their size cut-off for banding chicks, and the difference was due to differences in researcher judgement. Return rates were assessed for banded chicks, as was the probability of their
Table 1. Number of Adélie penguin chicks weighed, measured and banded just prior to fledging at capes Royds, Bird, and Crozier colonies, and total weighed but not necessarily banded, from 2001 to 2016

\begin{tabular}{|c|c|c|c|c|c|c|}
\hline \multirow[t]{2}{*}{ Year } & \multicolumn{2}{|c|}{ - Royds -} & \multicolumn{2}{|c|}{$\longrightarrow$ Bird -} & \multicolumn{2}{|c|}{ - Crozier } \\
\hline & Banded & Total & Banded & Total & Banded & Total \\
\hline 2001 & 14 & 14 & & 50 & 43 & 30 \\
\hline 2002 & 47 & 50 & & 50 & 47 & 50 \\
\hline 2003 & & 21 & & 30 & & 37 \\
\hline 2004 & 55 & 56 & & 31 & & 40 \\
\hline 2005 & & 30 & & 52 & & 42 \\
\hline 2006 & & 15 & 48 & 50 & & 50 \\
\hline 2007 & 28 & 29 & & 45 & & 38 \\
\hline 2008 & & 30 & & 50 & & 25 \\
\hline 2009 & 31 & 31 & 100 & 49 & & 29 \\
\hline 2010 & 28 & 28 & 100 & 46 & & 42 \\
\hline 2011 & 30 & 30 & & 46 & & 47 \\
\hline 2012 & 104 & 104 & & 48 & 223 & 48 \\
\hline 2013 & & & & 40 & & 18 \\
\hline 2014 & & & & & & 88 \\
\hline 2015 & & 15 & & & & 86 \\
\hline 2016 & & 97 & & & & 150 \\
\hline
\end{tabular}

return in subsequent years relative to initial body condition.

Adélie penguin chicks reach peak mass at about $6 \mathrm{wk}$, then lose 10 to $15 \%$ of mass before fledging. We used the growth curves of several studies (Taylor \& Roberts 1962, Ainley \& Schlatter 1972, Volkman \& Trivelpiece 1980, Salihoglu et al. 2001, Chapman et 
al. 2011, Jennings unpubl. data) to determine average post-peak loss $(\sim 12 \pm 2.6 \% \mathrm{SD})$. We used this value to correct measured mass to estimate mass at fledging 1 to 2 wk later (adjusted mass, hereafter AdjMass). We did this relative to mean chick age at the time of that last measurement (5 to $6 \mathrm{wk}$ ), which was estimated using mean hatch date at each colony (at Cape Royds the mean peak hatch date was 3 to $10 \mathrm{~d}$ later than at capes Bird and Crozier, depending on the year; authors' unpubl. data). When the final mass was measured 1 wk before the age of peak mass, we made no adjustment, as mass should be similar to the post-peak decrease. Adjustments were made in most years, except for Cape Crozier in 2004, 2006, and 2010.

We also weighed and measured a sample of chicks who were not banded, just prior to fledging from 2001 to 2016. AdjMass was estimated as for banded chicks. The combined sample of chick mass from both banded and unbanded birds was used to evaluate general patterns in fledging mass by colony over time, and in relation to chick diets (see below).

\section{Band re-sighting}

Each of the 3 Ross Island colonies was searched for birds banded from 1997 to 2016 at 2 to 7 d intervals (depending on the colony) throughout the breeding season; bands were read with binoculars from a distance of 5 to $10 \mathrm{~m}$. Thus, birds were not physically recaptured, and identification of individuals occurred through re-sighting band numbers. Sightings were also made intermittently at Beaufort Island (19992004, 2005-2007 and 2009-2010) but these data were used only when a penguin banded at Ross Island was sighted at Beaufort Island (see LaRue et al. 2013). Data from the oldest cohorts of chicks measured $(2001,2002,2004)$ indicated that, of the individuals seen again, none were seen before $2 \mathrm{yr}$ of age (i.e. subadults in an 'unobservable state' until age 2), and most had returned to at least 1 of the 3 Ross Island colonies or Beaufort island for the first time as either a pre-breeder or breeder by the age of $5(\bar{x}=92.8 \%)$. Thus, to index subadult survival (fledging to age 2), we used re-sighting data from chicks banded from 1997 to 2012 to estimate the probability of surviving to return at least once by the time they were $5 \mathrm{yr}$ of age. We did not include banded cohorts with $<5 \mathrm{yr}$ of potential re-sighting data to be sure we were allowing enough re-sighting years to assign returned status for all cohorts included in the analysis. Banded chicks seen at least once by age 5 at Ross Island (or
Beaufort) (in other words, cumulative return rates) were considered 'returned' and coded as ' 1 ', even if they returned to a non-natal colony (relatively rare); those who were not seen were coded as ' 0 '.

\section{Chick diets}

We assessed the chick diet during the provisioning period at Cape Royds in 12 years (2003-2012, 20152016), at Cape Bird over 8 yr (2004 to 2011) and at Cape Crozier over 14 yr (2003 to 2016). The mix of observers was the same for the entire data collection effort at Cape Royds. At capes Bird and Crozier, there was a slow change in observers, with most present for several years; personnel turned over mid-season, but new individuals overlapped with original crew members long enough within years to calibrate new personnel and maintain integrity of the data collection. Using binoculars, we observed the color and consistency of food as it was regurgitated by parents to chicks every day after 7 January at capes Crozier and Bird, and 15 January at Cape Royds. Pink paste was considered to be mainly krill while gray, more granular food was mainly fish (see Fig. A1 in the Appendix). The proportion of pink versus gray matter reflected the ratio of crystal krill to Antarctic silverfish in the diets of individual penguins. This method of diet determination, and identification of Antarctic silverfish and crystal krill as the 2 primary components of penguin diet, was confirmed experimentally using stomach pumping early in our study (Ainley et al. 1998, 2003b; see also Ainley et al. 2006, Whitehead et al. 2015). Silverfish is the only forage fish species that occurs in the upper water column of the Ross Sea marginal ice zone (Eastman 1985). We averaged individual diet observations to estimate the average proportion of krill:fish fed to chicks each day during the crèche stage of chick-rearing at all 3 colonies. This included chicks aged 3 to $6 \mathrm{wk}$ at Crozier and Bird, and chicks aged 2 to 5 wk at Cape Royds (Table 2 contains sample size of observations).

\section{Data analyses}

We used a logistic regression model to evaluate the fixed effects of chick mass (AdjMass), fledging cohort (year chick fledged; categorical variable) and natal colony on the probability that a chick returned to any Ross Island colony by age 5 . We developed an a priori model set to evaluate AdjMass, as well as cohort and natal colony as single factors in the model. Then we 
Table 2. Average proportion of fish in Adélie penguin chick diets at each colony in the period before fledging (after 7 January at Crozier and Bird; after 15 January at later-breeding Royds), with the sample size (n) of observations indicated for each colony-year

\begin{tabular}{|lcccccc|}
\hline Year & Royds & $\mathrm{n}$ & Bird & $\mathrm{n}$ & Crozier & $\mathrm{n}$ \\
\hline 2003 & 0.505 & 47 & & & 0.630 & 28 \\
2004 & 0.591 & 24 & 0.304 & 26 & 0.672 & 213 \\
2005 & 0.446 & 30 & 0.682 & 149 & 0.605 & 377 \\
2006 & 0.787 & 113 & 0.285 & 91 & 0.442 & 178 \\
2007 & 0.329 & 125 & 0.433 & 63 & 0.644 & 127 \\
2008 & 0.440 & 53 & 0.634 & 22 & 0.391 & 62 \\
2009 & 0.279 & 51 & 0.59 & 16 & 0.298 & 161 \\
2010 & 1.000 & 7 & 0.561 & 129 & 0.419 & 144 \\
2011 & 0.663 & 21 & 0.520 & 21 & 0.199 & 36 \\
2012 & 0.267 & 42 & & & 0.232 & 56 \\
2013 & & & & & 0.102 & 60 \\
2014 & 0.495 & 80 & & & 0.083 & 41 \\
2015 & 0.750 & 36 & & & 0.561 & 40 \\
2016 & 0.335 & 40 & & & 0.534 & 156 \\
Mean & 0.530 & & 0.435 & & 0.415 & \\
SE & 0.061 & & 0.074 & & 0.053 & \\
\hline
\end{tabular}

investigated models with AdjMass as an additive or interaction effect with either cohort or colony (both categorical variables). Because our sampling design did not include samples from all colonies in all years (Table 1), we did not include both cohort and colony in the same model. We z-transformed (i.e. standardized or auto-scaled) AdjMass prior to including it in the model to facilitate model convergence (Bates et al. 2018).

We used an information-theoretic approach (Burnham \& Anderson 2002) and Akaike's information criterion corrected for small sample sizes $\left(\mathrm{AIC}_{\mathrm{c}}\right)$ to determine the best model from our a priori model set. We selected the model with the lowest $\mathrm{AIC}_{\mathrm{c}}$ value and highest Akaike weight as our best model, but models within $2 \mathrm{AIC}_{\mathrm{c}}$ units $\left(\Delta \mathrm{AIC}_{\mathrm{c}} \leq 2.0\right)$ were considered competitive (Burnham \& Anderson 2002). We also evaluated the strength of evidence for specific effects in competing models by assessing the degree to which $95 \%$ confidence intervals $(95 \% \mathrm{CI}$, based on profile likelihoods) for slope coefficients $(\hat{\beta})$ overlapped zero (Arnold 2010, Forsman et al. 2011). Covariates with $95 \% \mathrm{CI}$ that did not overlap zero were considered to have the strongest evidence of an effect, whereas covariates with $\leq 10 \%$ of the $95 \%$ CI overlapping zero ('slightly' overlapping) were considered to have less evidence of an effect. Covariates with confidence limits with $>10 \%$ of the interval above or below zero ('widely' overlapping) were considered to have no support (Forsman et al. 2011).
We calculated Spearman rank correlations between diet and year, diet and adjusted chick mass for all chicks (banded and not banded), and diet and return rates for all the years in which variables were available (see 'Chick diets' and 'Chick measurements' above). We used the package 'Ime4' in program R to generate models, model estimates, and model selection results (Bates et al. 2015, 2018) and the R Stats package version 3.4.3 (R Core Team 2016) to calculate correlation coefficients and p-values (results were considered significant at $p<0.05$ ) and to generate all other summary statistics. Means and standard errors are presented unless otherwise noted.

\section{RESULTS}

We measured the mass of 898 chicks banded just prior to fledging in 9 years from 1996 to 2012 (Table 1). A total of 183 of these chicks ( 20\%) returned to our metapopulation at least once by age 5 (Table 3 ). The probability that any of these chicks returned was positively related to their mass at fledging, but also varied by cohort (AdjMass; Table 4, Fig. 2). The additive effects of fledging cohort and adjusted mass were strongly supported by model selection results $\left(\mathrm{AIC}_{\mathrm{c}}\right.$ wt. $\left.=0.970\right)$ with no support for an interaction between cohort and AdjMass or colony, either alone or in combination with AdjMass (Table 4). The high-

Table 3. Number of Adélie penguin chicks by cohort and age at 1st re-sighting that were detected at capes Royds, Bird, and Crozier after banding and weighing at fledging. The total number returned at least once by $5 \mathrm{yr}$ of age, and as a percentage of total banded/weighed each fledging year are included for reference

\begin{tabular}{|lcccccc|}
\hline Colony & Cohort & Age & Age & Age & Age & Total \\
& & 2 & 3 & 4 & 5 & (\% returned) \\
\hline Royds & 2001 & 0 & 1 & 4 & 1 & $6(43)$ \\
& 2002 & 0 & 2 & 5 & 2 & $9(19)$ \\
& 2004 & 2 & 3 & 2 & 1 & $8(15)$ \\
& 2007 & 1 & 2 & 2 & 1 & $6(21)$ \\
& 2009 & 1 & 5 & 1 & 1 & $8(26)$ \\
& 2010 & 1 & 5 & 0 & 2 & $8(29)$ \\
& 2011 & 1 & 0 & 3 & 0 & $4(13)$ \\
& 2012 & 0 & 8 & 3 & 3 & $14(13)$ \\
Bird & 2006 & 0 & 7 & 12 & 6 & $25(52)$ \\
& 2009 & 1 & 16 & 8 & 1 & $26(26)$ \\
& 2010 & 10 & 12 & 5 & 1 & $28(28)$ \\
Trozier & 2001 & 2 & 8 & 0 & 0 & $10(23)$ \\
& 2002 & 6 & 5 & 4 & 0 & $15(32)$ \\
& 2012 & 3 & 10 & 3 & 0 & $16(7)$ \\
& & 28 & 84 & 52 & 19 & $183(20)$ \\
\hline \multirow{6}{*}{ Total } & & & & & & \\
\hline
\end{tabular}


est return rates among years were observed during 2006 (mean $=0.52 \pm 0.008$ ), and the lowest during 2012 (0.09 \pm 0.002 ; Fig. 2). Mean fledging mass for chicks that returned was $3408 \pm 41.5 \mathrm{~g}$ (range: 1679 to $4988 \mathrm{~g}_{i}$ median: $3444 \mathrm{~g}$ ) versus $3189 \pm 25.1 \mathrm{~g}$ (range: 1460 to $5066 \mathrm{~g}$; median: $3192 \mathrm{~g}$ ) for those who did not return (Fig. 3), a difference of $219 \mathrm{~g}(6.5 \%)$. The estimated probability of a chick returning by age 5 increased 1.34 times (Table 5) per $655 \mathrm{~g}$ increase in

Table 4. Model selection results for logistic regression models evaluating the effect of adjusted mass (AdjMass), cohort, and colony on the probability that an Adélie penguin chick returns by age 5 to Royds, Bird or Crozier colonies. Model results include Akaike's information criteria adjusted for small sample size $\left(\mathrm{AIC}_{\mathrm{c}}\right.$ ) (lowest $\mathrm{AIC}_{\mathrm{C}}=852.44$ ), differences between model $\mathrm{AIC}_{\mathrm{c}}$ and the $\mathrm{AIC}_{\mathrm{c}}$ from the top model $\left(\Delta \mathrm{AIC}_{\mathrm{c}}\right), \mathrm{AIC}_{\mathrm{c}}$ weights $\left(w_{i}\right)$, model deviance, and the number of parameters $(K)$. The intercept-only model with no fixed effects are included for comparison

\begin{tabular}{|lrccc|}
\hline Model & $\Delta \mathrm{AIC}_{\mathrm{c}}$ & $W_{i}$ & Deviance & $K$ \\
\hline Cohort + AdjMass & 0.00 & 0.970 & 832.44 & 10 \\
Cohort & 7.32 & 0.025 & 841.81 & 9 \\
Cohort × AdjMass & 10.45 & 0.005 & 826.36 & 18 \\
Colony + AdjMass & 23.06 & 0.000 & 867.72 & 3 \\
Colony × AdjMass & 25.69 & 0.000 & 866.29 & 6 \\
Colony & 31.48 & 0.000 & 878.14 & 3 \\
AdjMass & 42.93 & 0.000 & 891.61 & 2 \\
Intercept-only & 58.01 & 0.000 & 908.07 & 1 \\
& & & & \\
\hline
\end{tabular}

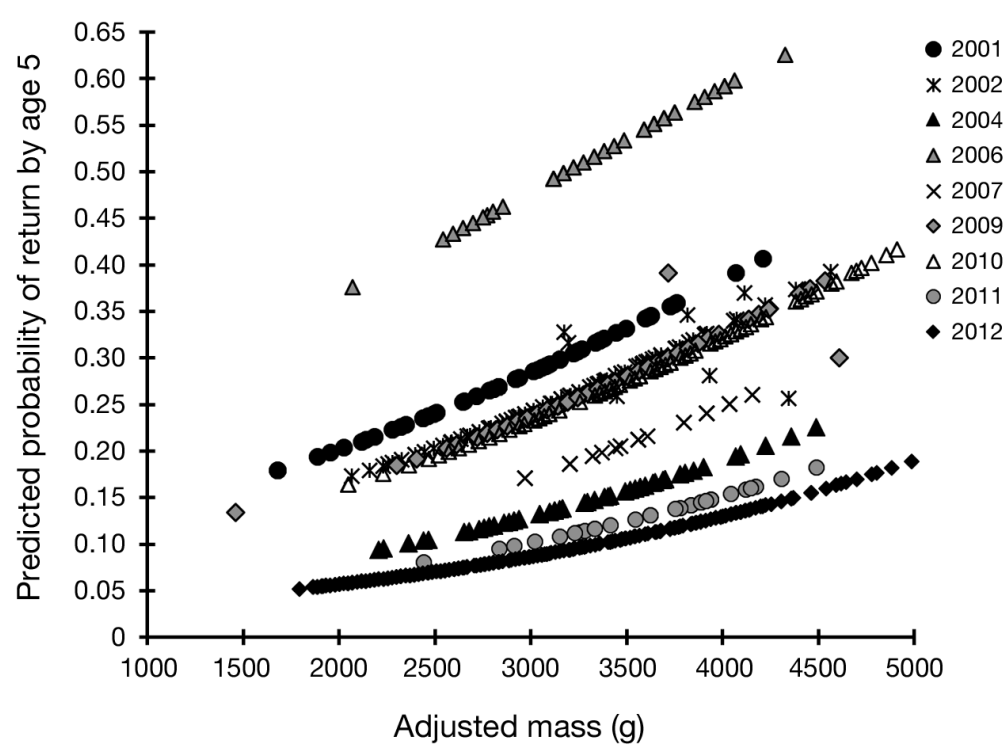

Fig. 2. Estimates, by cohort, of the predicted probability that a fledged Adélie penguin chick returns to Ross Island (by age 5) relative to adjusted fledging mass (AdjMass), for each fledging cohort, determined by the best logistic regression model with cohort and AdjMass (scaled) as additive main effects mass at fledging $(655 \mathrm{~g}=$ standard deviation of AdjMass) within each fledging cohort.

We measured mass ( $\mathrm{g}$ ) of $>2000$ chicks just prior to fledging (banded and not banded) from 2001 to 2016 at all 3 colonies combined (Table 1). Chicks generally fledged at higher mass at Cape Royds $(3473 \pm 84.1 \mathrm{~g})$ than at either Cape Bird $(3197 \pm 82.0 \mathrm{~g})$ or Cape Crozier (2865 \pm 70.8 g; Fig. 4). We observed no significant relationship between the AdjMass at fledging (Table 6) and the proportion of silverfish in the diet at any of the colonies, or between return rate and diet composition (Table 6). However, we did find a negative trend in the proportion of fish in the diet at Cape Crozier over time (Table 6), in accord with previous findings of a generally decreasing peak mass when a chick reached age 5 wk (Whitehead et al. 2015).

\section{DISCUSSION}

We previously reported an inverse relationship between Adélie penguin colony size and chick mass at age $5 \mathrm{wk}$, the growth peak, when chicks had the lowest mass and poorest condition at the very large colony at Cape Crozier, and highest mass at the very small Cape Royds colony (Whitehead et al. 2015) (Fig. 4). Interannual variation in the mass and condition of chicks at Week 5 was indeed negatively related to colony size (Dugger et al. 2014), with colony size in any year reflecting the proportion of breeding adults (from Lyver et al. 2014). Thus, we concluded that intraspecific competition for food, and subsequent depletion of prey, was the main driver of prey availability and in turn chick growth rates and near-fledging mass (measured at 5 wk) (Whitehead et al. 2015; see below). In other words, negative alteration of the preyscape (quality and proximity of prey patches) during chick-rearing was when food resources could become limiting, negatively affecting overall reproductive success. As population size increased at capes Bird and Crozier, greater parental foraging effort and increased efficiency were required and could result in chicks receiving smaller and/or less frequent meals at the bigger colonies (Ainley et al. 2006, 2015). At Cape Crozier, this is in part due to the need to expand the foraging area throughout the breeding season, as penguin foraging decreases the prevalence of high-quality prey patches 


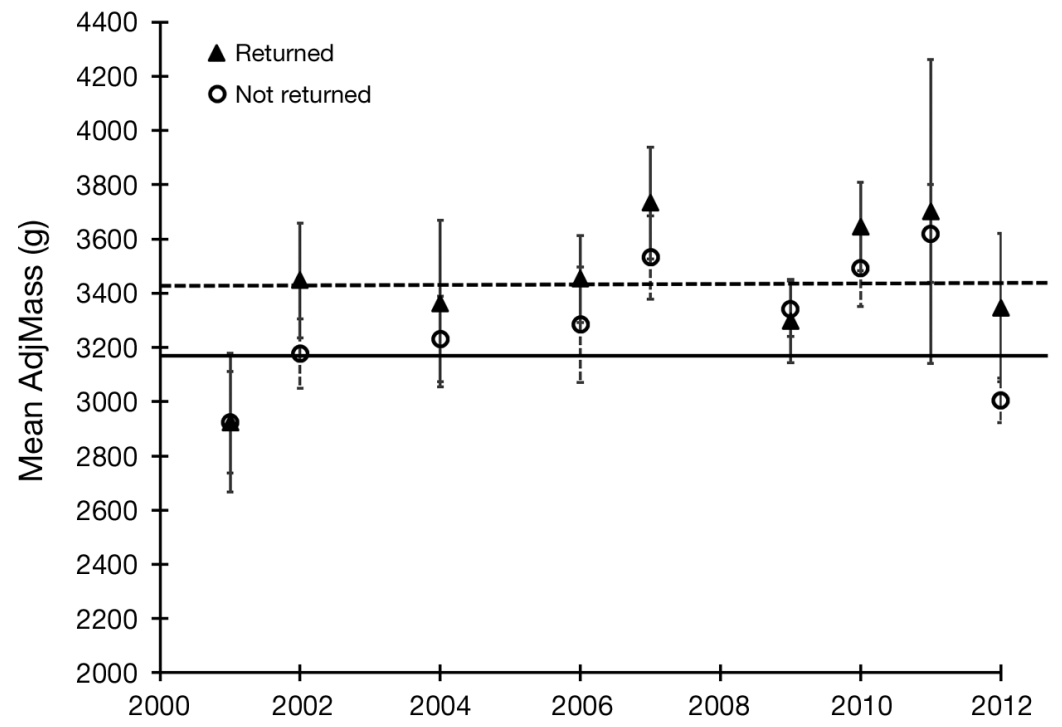

Fig. 3. Mean $( \pm 95 \% \mathrm{CI})$ adjusted fledging mass (AdjMass) by return status (returned by 5 yr of age or not) for banded Adélie penguin chicks at capes Royds, Bird, and Crozier during 2001-2002, 2004, 2006-2007, and 20092012. Mean fledging mass for chicks that returned (3402 g; dashed line) and chicks that did not return (3188 g; solid line) across all years is included for reference

Table 5. Model coefficients ( $\hat{\beta})$ with standard errors (SE) and $95 \%$ confidence limits (LCL: lower confidence limit; UCL: upper confidence limit) for fixed effects from the best predictive logistic regression model relating adjusted Adélie penguin chick fledging mass (AdjMass) and fledging cohort to chick return rates from chicks banded during 2002 to 2012 at capes Royds, Bird, and Crozier on Ross Island, Antarctica. Odds ratios $\left(\mathrm{e}^{\hat{\beta}}\right)$ for model coefficients are also included

\begin{tabular}{|lrcrrr|}
\hline Model & $(\hat{\beta})$ & SE & LCL & UCL & $\begin{array}{c}\text { Odds } \\
\text { ratio }\end{array}$ \\
\hline $\begin{array}{l}\text { Intercept (2001 } \\
\text { as reference) }\end{array}$ & -0.817 & 0.299 & -1.431 & -0.250 & 0.44 \\
2002 & -0.274 & 0.383 & -1.021 & 0.488 & 0.76 \\
2004 & -0.981 & 0.488 & -1.981 & -0.049 & 0.38 \\
2006 & 0.839 & 0.419 & 0.027 & 1.676 & 2.31 \\
2007 & -0.642 & 0.556 & -1.795 & 0.414 & 0.53 \\
2009 & -0.287 & 0.363 & -0.989 & 0.462 & 0.75 \\
2010 & -0.275 & 0.369 & -0.989 & 0.462 & 0.76 \\
2011 & -1.248 & 0.624 & -2.598 & -0.100 & 0.29 \\
2012 & -1.432 & 0.356 & -2.122 & -0.720 & 0.24 \\
AdjMass & 0.293 & 0.096 & 0.105 & 0.483 & 1.34 \\
\hline
\end{tabular}

near the colony, leading to longer foraging trips as the season progresses, and lower foraging efficiency than at Cape Bird and Cape Royds (Ainley et al. 1998, 2015, Ballance et al. 2009, Lescroël et al. 2010, Ford et al. 2015). These overall patterns are presented in greater detail below.

\section{Fledging mass affects subsequent rate of recruitment}

In the present study, we investigated the relationship between estimated chick mass at fledging and the probability of subsequent return. Whether or not differential return according to gender was involved we do not know, though with continued years of research we may some day have sufficient data to consider this subject (see Maness \& Anderson 2013). Interestingly, at Cape Crozier, in all but 2 of the 16 years the mean fledging mass was less than the mean of all chicks who returned to Ross Island colonies by age 5. Furthermore, it was only in the first $2 \mathrm{yr}$ of our time series that average chick mass at Cape Crozier was close to the island-wide mean. Assuming generally that high fledging mass has positive demographic consequences (Hinke et al. 2007), this result is surprising for a colony that has steadily increased to become one of the largest for this species (see Lynch \& LaRue 2014). Immigration from nearby colonies, though certainly apparent at a low level, cannot explain the colony increases at Cape Crozier or Cape Bird (Dugger et al. 2010, 2014, LaRue et al. 2013). Therefore, there appears to be a rich preyscape existing beyond the foraging areas (Ballance et al. 2009) of the Ross Island colonies; one that the numerous Crozier fledglings can readily exploit to make up for reduced diet during the provisioning period (and resulting low fledging mass), even as the number of fledglings produced each year increases in conjunction with increased breeding populations.

Young penguins that returned to Ross Island averaged $3.4 \pm 0.0411 \mathrm{~kg}$ at fledging compared to $3.2 \pm 0.0251 \mathrm{~kg}$ at fledging for those that did not return (6.1\% difference). These values were well above those calculated for Anvers Island (3.2 vs. $3.0 \mathrm{~kg}$, respectively; $4.5 \%$ difference) (Chapman et al. 2010). In both studies, these differences in the mass of fledglings that returned versus those that did not return are of the same order of magnitude as those measured in other seabirds, such as Cory's shearwater Calonectris diomedea $4.7 \%$ (Mougin et al. 2000), sooty shearwater Ardenna grisea 5.4 to $13 \%$ (Sagar \& Horning 1998), Manx shearwater 


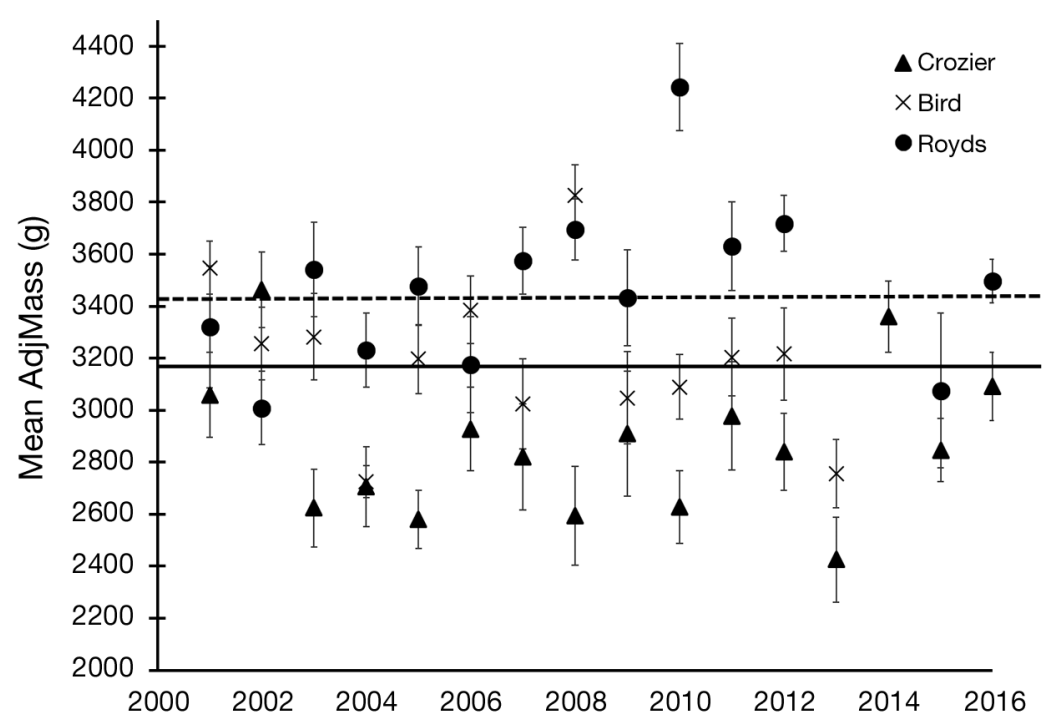

Fig. 4. Mean ( $\pm 95 \%$ CI) adjusted fledging mass (AdjMass) of all Adélie penguin chicks weighed and measured before fledging (banded and not banded) at capes Royds, Bird, and Crozier during 2001-2016. Mean fledging mass for banded chicks that returned (3402 g; dashed black line) and chicks that did not return (3188 g; solid black line) are included for reference

Table 6. Spearman rank correlation coefficients, p-values and sample size (n) for the proportion of fish in the diet of Adélie penguin chicks, adjusted fledging mass (AdjMass) and year for all chicks, and return rates for banded chicks, at capes Royds, Bird, and Crozier. Sample size reflects the number of years that diet data were available on each colony between 1996 and 2016, and for all colony/year combinations for banded chicks. Bold denotes significant correlations at $\mathrm{p}=0.05$

\begin{tabular}{|lrcrcrrr|}
\hline & AdjMass & $\mathrm{p}$ & Year & $\mathrm{p}$ & $\begin{array}{c}\text { Return } \\
\text { rate }\end{array}$ & $\mathrm{p}$ & $\mathrm{n}$ \\
\hline Cape Royds & -0.056 & 0.87 & -0.126 & 0.70 & & & 12 \\
Cape Bird & 0.381 & 0.36 & 0.048 & 0.94 & & & 8 \\
Cape Crozier & -0.288 & 0.32 & $\mathbf{- 0 . 5 8 7}$ & $\mathbf{0 . 0 3}$ & & & 14 \\
All colonies & & & & & 0.165 & 0.57 & 14 \\
\hline
\end{tabular}

Puffinus puffinus $8.5 \%$ (Perrins et al. 1973), and king penguin $3.2 \%$ (Olsson 1997). In addition, the return rate of chicks fledged from Ross Island averaged $\sim 21 \%$ across all years (range $9 \%$ in 2012 to $52 \%$ in 2006) compared to $7 \%$ for the chicks fledged at Anvers Island (see Chapman et al. 2010). In all but 2 years $(2011,2012)$, the return rates of chicks from Ross Island were more than twice as high as the overall return rate for chicks on Anvers Island. At Cape Crozier, the mean annual fledging mass was often below the mean of chicks that did not return to Anvers Island (i.e. $3.0 \mathrm{~kg}$ ); the predicted return rates for these lighter chicks was $\sim 10 \%$.

\section{Characterization of preyscape within colony foraging areas}

Despite the strong relationship between population size, foraging trip duration, and foraging area size, and the negative one to peak chick mass and eventual recruitment, the large colony at Cape Crozier doubled in population during our study in accord with generally increasing colonies in the southern Ross Sea (Lyver et al. 2014, Whitehead et al. 2015). Thus, food seems to have been abundant and available in the Ross Sea region. However, a reduction of high-quality prey patches (i.e. reduced prey availability) near the biggest breeding colony appears to have made it harder for parents to provision their chicks as the colony kept growing. Although we did not annually examine whether the foraging area of the population at Cape Crozier changed over the course of the study, after quantifying foraging ranges during 1997 to 2000 (Ainley et al. 2004) and 2005 to 2007 (Ford et al. 2015), we investigated them once again in 2012 in conjunction with quantifying the preyscape (Ainley et al. 2015, Saenz et al. 2018). No changes in foraging areas were evident, other than from a 3D perspective there was an expansion deeper and northward in the Crozier colony foraging area (but not Royds colony foraging area) as high-quality prey patches within the marginal ice zone of the Ross Sea Polynya (Fig. 1) became more distant from the colony at Cape Crozier (cf. Ainley et al. 2015, Ford et al. 2015, Saenz et al. 2018).

We quantified the preyscape in conjunction with penguin foraging behavior off capes Royds and Crozier in 2012, using biologging of penguins in conjunction with acoustically equipped gliders and remotely operated vehicles. We found that Crozier penguins depleted prey near the colony and had to make increasingly longer trips, and also dived deeper to find food near the colony as the season progressed. That contrasted with Royds, where penguins depleted shallow prey but not to the extent that they had to increase foraging depth or foraging 
range (Ainley et al. 2015, Saenz et al. 2018). It seems to us that prey availability off Royds actually represented an under-utilized preyscape outside of the Crozier foraging area (cf. Ainley et al. 2004, 2015, Saenz et al. 2018). High-quality prey patches remained close to Cape Royds, unlike the waters off Cape Crozier where these became farther away (see Ford et al. 2015). It is unlikely that the prey shifted on their own, because penguins continued to forage (though less efficiently) upon encountering a usually lower quality patch during their commute to the outer reaches of the expanding foraging area. For African penguins Spheniscus demersus, prey availability outside the foraging area of breeding birds can have important demographic consequences for fledglings (Weller et al. 2014) (see below).

\section{Role of Antarctic silverfish in penguin demographic trends}

In contrast to Cape Crozier, the Adélie penguin population at Anvers Island has been decreasing continuously over the past $~ 30 \mathrm{yr}$, from 15000 pairs in the mid-1970s to <3000 pairs by 2009, comparable in size to the Cape Royds colony (Schofield et al. 2010). At Anvers Island, a high prevalence of energydense silverfish in the diet was important for chicks to obtain an adequate fledging mass (Chapman et al. 2011). The peak body mass of chicks from Ross Island was also positively related to the proportion of fish in their diet; also, faster-growing male chicks were fed more fish than female chicks (Whitehead et al. 2015, Jennings et al. 2016). Chicks from Anvers Island that fledged at higher mass had a greater probability to return as subadults than lighter chicks, and to do so had to receive a diet composed of at least $20 \%$ silverfish (up to 50\%; Chapman et al. 2011). In recent decades, diet composition at Anvers Island has apparently reached that threshold in fewer years, a possible explanation for the decreasing population (Sailley et al. 2013). At capes Crozier, Bird and Royds, in the few weeks prior to fledging, the chick diets averaged $41.5,43.5$ and $53.0 \%$ fish, respectively, and ranged from 8.3 to $67.2 \%$ at Cape Crozier, 6 to $68.2 \%$ at Cape Bird, and 26.7 to $78.7 \%$ at Cape Royds.

At Cape Crozier, the proportion of silverfish in the chick diet declined significantly over time, reaching zero by 2014 with a marked resurgence thereafter. The decline in the proportion of fish in the diet is in accord with the overall decrease in fledging mass, and coincides with our lowest mean return rate estimated for the chicks near the end of our study in 2012
(9\%; Fig. 2). However, despite the decrease in dietary prevalence of fish for several years, return rates were still higher than at Anvers Island, and the Crozier colony continued to increase (Lyver et al. 2014, Antarctica NZ unpubl. data).

Clearly, there is still much to learn about the preyscape in the penguin foraging areas off Ross Island. While numerous studies assume that variation in fledging mass of seabirds is a measure of variation in prey availability during the chick feeding period (Ainley \& Boekelheide 1990, Olsson 1997, Golet et al. 2000, Davoren \& Montevecchi 2003b, Hinke et al. 2007, Chapman et al. 2010, Waluda et al. 2012), other factors may also be very important. For instance, in Adélie penguins, parental body condition affects provisioning of the chick (Ballard et al. 2010a; see also Tveraa et al. 1998 and Wendeln \& Becker 1999 for other seabird species). While the latter studies addressed inter-individual parental provisioning, it is possible that colony-wide average parental condition can lead to changes in fledging mass. Parental body condition is a function of parental foraging effort and success before or early in the breeding season. Variation in parental condition might be one reason why we found no direct interannual connection between diet and fledging mass at Cape Royds and Cape Bird. On the other hand, the observed proportion of silverfish in the diet may always be above some important threshold such that variation in other factors is statistically more strongly associated with variation in chick mass. During 13 of 14 years of data, the average proportion of fish in the diet for Ross Island penguins was $>20 \%$, and sometimes 2 or 3 times that amount; this was the threshold suggested for the chick mass necessary for subsequent recruitment offered by Chapman et al. (2011). Silverfish in the diet of penguins on Ross Island generally far exceeded that at Anvers Island, where the incremental loss of silverfish in the diet over recent decades may be important to the decreasing numbers of Adélie penguins there (Sailley et al. 2013). Interestingly, in the last decade in accord with the disappearance of sea ice, the silverfish population inhabiting the northwestern side of the Antarctic Peninsula has progressively declined and was virtually absent by 2010 (La Mesa et al. 2015). Consistent with that trend, the prevalence of fish as determined by stable isotope analysis in the Adélie penguin chick diet increases with latitude on the west coast of the Antarctic Peninsula from Anvers Island (64.8 $\left.{ }^{\circ} \mathrm{S}\right)$ southward to Avian $\left(67.8^{\circ} \mathrm{S}\right)$ and Charcot $\left(69.8^{\circ} \mathrm{S}\right)$ islands (Gorman 2015), in accord with increasing presence of sea ice (Stammerjohn et al. 2012). 


\section{Prevalence of Antarctic silverfish in the southern Ross Sea}

The long period of decrease in the prevalence of silverfish in the diet of penguins at Cape Crozier is interesting. As the colony grew, parent birds may have become increasingly burdened by growing competition, and may have compensated by taking an increasing portion of the available, high-energydense silverfish, thereby driving down local fish biomass in a top-down fashion (as shown by Ainley et al. 2015, Saenz et al. 2018, comparing the preyscape off capes Crozier and Royds, respectively). However, in 2015 and 2016, silverfish became again more prevalent in the Crozier penguins' diet. This discontinuity cannot be explained by changes in personnel making the observations. Silverfish are not a well-studied species, despite their importance to the Antarctic neritic food web (Eastman 1985, La Mesa \& Eastman 2012), and interannual time series of abundance or age structure are lacking. Silverfish can reach $14 \mathrm{yr}$ of age, but the modal age in the Ross Sea is 6 to $9 \mathrm{yr}$ (Sutton \& Horn 2011). Silverfish may be well mixed in the western Ross Sea, without much evidence of an effect of a strong subadult year class sustaining the stock for extended periods (Davis et al. 2017, Brooks et al. 2018). Thus, it is unlikely that different subpopulations occur in the southern Ross Sea and in McMurdo Sound, and that the penguins from Cape Crozier depleted one infrequent strong year class of fish. The gradual decrease in silverfish in the penguins' diet could be due to progressively more intensive predation by penguins and other predators, as indicated in the preyscape comparison between capes Royds and Crozier during 2012 (Ainley et al. 2015, Saenz et al. 2018). While a noticeable interannual variability of larval abundance is apparent, presumably driven by the timing of formation and extension of polynyas in summer (La Mesa et al. 2010), no long-term trend has been found and no information exists on how larval abundance might affect the portion of the silverfish stock exploited by upper trophic level predators. In accord, at Ross Island, Adélie penguins have not responded to interannual variation in polynya size and subsequent phytoplankton abundance (Dugger et al. 2014).

The decreasing prevalence of a competitor for silverfish, the Antarctic toothfish Dissostichus mawsoni, could well be providing more silverfish to the penguins (Ainley et al. 2017). This might seem especially pertinent outside of the large foraging area of the Cape Crozier colony (compare foraging areas in Ainley et al. 2004, 2015, Ford et al. 2015, Saenz et al.
2018), and may explain how the colony can continue to expand despite increasingly underweight fledglings. Although the foraging areas of the small colonies at capes Royds and Bird (and Beaufort Island) greatly overlap, they occur just outside the foraging area of penguins from Cape Crozier and appear to shift to avoid the seasonally increasing Crozier foraging area (Ainley et al. 2004; Fig. 1). Moreover, many adults from Cape Royds remain near the colony to molt, in contrast to penguins from Cape Crozier who travel to the eastern Ross Sea continental slope to molt (Ballard et al. 2010b). It is yet to be determined whether the distribution and relative availability of the energy-dense prey influences the disparate patterns in penguin residency tenure. More research is needed on food web dynamics in the southwestern Ross Sea.

Acknowledgements. We thank the following people for help in the field during the past $20 \mathrm{yr}$ at 3 colonies: C. Adams, J. Adams, S. Allen, L. Ballance, G. Barclay, Q. Barr-Glintborg, L. Blight, J. Blum, E. Burke, H. Carrad, W. Cook, K. Drew, P. Dilks, L. Doel, I. Gaffney, C. Gjerdrum, D. Hardesty, S. Heath, M. Hester, D. Jongsomjit, P. Kappes, K. Lindquist, C. McCreedy, V. Morandini, H. Nevins, R. Orben, V. Patil, R. Pech, A. Pollard, E. Porzig, C. Ribic, B. Saenz, L. Sheffield, L. Smith, I. Sutherland, Y. Suzuki, C. Thomson, P. Timoti, V. Toniolo, A. Varsani, S. Webb, D. Wilson, A. Whitehead, J. Whitehead, and S. Winquist. We thank E. Chapman, K. Gorman, K. Elliott and 2 anonymous reviewers for comments that improved the manuscript. Fieldwork was conducted with logistic support provided by the US Antarctic Program, through Antarctic Support Contractors, and Antarctica New Zealand. Permits were provided under the Antarctic Conservation Act, National Science Foundation Office of Polar Programs (2006-010, 2011-002, 2017-005) and Landcare Research Animal Ethics Committee Permit (0509/01). Data collection protocols used by D.G.A., K.M.D., G.B., A.L., A.S., and S.J. were approved by Oregon State University's Institutional Animal Care and Use Committee. Funding was provided by National Science Foundation Grants OPP 9526865, 9814882, 0125608, 0440643, 0944411 and 154398 (to K.M.D., D.G.A., and G.B.) and New Zealand Ministry of Business, Innovation, and Employment Grant (C09527, C09X0510, C01X1001) and NZ's Ministry for Primary Industries (MPI17238-S01-LC), with addenda (to P.O'B.L., K.J.B., and P.W.). Any use of trade, firm, or product names is for descriptive purposes only and does not imply endorsement by the US Government. This is Point Blue Conservation Science Contribution 2179.

\section{LITERATURE CITED}

Ainley DG, Boekelheide RJ (eds) (1990) Seabirds of the Farallon Islands: ecology, structure and dynamics of an upwelling-system community. Stanford University Press, Palo Alto, CA

Ainley DG, Schlatter RP (1972) Chick raising ability in Adélie penguins. Auk 89:559-566 
Ainley DG, Wilson PR, Barton KJ, Ballard G, Nur N, Karl B (1998) Diet and foraging effort of Adélie penguins in relation to pack-ice conditions in the southern Ross Sea. Polar Biol 20:311-319

Ainley DG, Ford RG, Brown ED, Suryan RM, Irons DB (2003a) Prey availability, interference competition, and the geographic structure of seabird colonies: a study of black-legged kittiwakes and forage fish in Prince William Sound, Alaska. Ecology 84:709-723

Ainley DG, Ballard G, Barton KJ, Karl BJ, Rau GH, Ribic CA, Wilson PR (2003b) Spatial and temporal variation of diet composition and quality within a presumed metapopulation of Adélie penguins. Condor 105:95-106

Ainley DG, Ribic CA, Ballard G, Heath S and others (2004) Geographic structure of Adélie penguin populations: size, overlap and use of adjacent colony-specific foraging areas. Ecol Monogr 74:159-178

Ainley DG, Ballard G, Dugger KM (2006) Competition among penguins and cetaceans reveals trophic cascades in the Ross Sea, Antarctica. Ecology 87:2080-2093

Ainley DG, Ballard G, Jones RM, Jongsomjit D, Pierce SD, Smith WO Jr, Veloz S (2015) Trophic cascades in the western Ross Sea, Antarctica: revisited. Mar Ecol Prog Ser 534:1-16

Ainley DG, Crockett EL, Eastman JT, Fraser WR and others (2017) How overfishing a large piscine mesopredator explains growth in Ross Sea penguin populations: a framework to better understand impacts of a controversial fishery. Ecol Modell 349:69-75

Arizaga J, Herrero A, Aldalur A, Cuadrado JF, Oro D (2015) Effect of pre-fledging body condition on juvenile survival in yellow-legged gulls Larus michahellis. Acta Ornithol 50:139-147

Arnold TW (2010) Uninformative parameters and model selection using Akaike's information criterion. J Wildl Manage 74:1175-1178

Ashmole NP (1963) The regulation of numbers of tropical oceanic seabirds. Ibis 103b:458-473

Ballance LT, Ainley DG, Ballard G, Barton K (2009) An energetic correlate between colony size and foraging effort in seabirds, an example of the Adélie penguin Pygoscelis adeliae. J Avian Biol 40:279-288

Ballard G, Dugger KM, Nur N, Ainley DG (2010a) Foraging strategies of Adélie penguins: adjusting body condition to cope with environmental variability. Mar Ecol Prog Ser 405:287-302

* Ballard G, Toniolo V, Ainley DG, Parkinson CL, Arrigo KR, Trathan PN (2010b) Responding to climate change: Adélie penguins confront astronomical and ocean boundaries. Ecology 91:2056-2069

Bates D, Mächler M, Bolker B, Walker S (2015) Fitting linear mixed-effects models using lme4. J Stat Softw 67:1-48

Bates D, Maechler M, Bolker B, Walker S (2018) lme4: linear mixed-effects models using Eigen and S4. R package version 1.1-15. http://CRAN.R-project.org/package=lme4

Brooks CM, Caccavo JA, Ashford J, Dunbar R, Goetz K, La Mesa M, Zane L (2018) Early life history connectivity of Antarctic silverfish (Pleuragramma antarctica) in the Ross Sea. Fish Oceanogr 27:274-287

Brown CR, Brown MB (1996) Coloniality in the cliff swallow: the effect of group size on social behavior. University of Chicago Press, Chicago, IL

Burnham KP, Anderson DR (2002) Model selection and multimodel inference: a practical information-theoretic approach, 2nd edn. Springer-Verlag, New York, NY
Cam E, Monnat JY, Hines JE (2003) Long-term fitness consequences of early conditions in the kittiwake. J Anim Ecol 72:411-424

* Chapman EW, Hofmann EE, Patterson DL, Fraser WR (2010) The effects of variability in Antarctic krill (Euphausia superba) spawning behavior and sex/maturity stage distribution on Adélie penguin (Pygoscelis adeliae) chick growth: a modeling study. Deep Sea Res II 57:543-558

* Chapman EW, Hofmann EE, Patterson DL, Ribic CA, Fraser WR (2011) Marine and terrestrial factors affecting Adélie penguin Pygoscelis adeliae chick growth and recruitment off the western Antarctic Peninsula. Mar Ecol Prog Ser 436:273-289

Cimino MA, Moline MA, Fraser WR, Patterson-Fraser DL, Oliver MJ (2016) Climate-driven sympatry may not lead to foraging competition between congeneric top-predators. Sci Rep 6:18820

Davis LB, Hofmann EE, Klinck JM, Piñones A, Dinniman MS (2017) Distributions of krill and Antarctic silverfish and correlations with environmental variables in the western Ross Sea, Antarctica. Mar Ecol Prog Ser 584:45-65

* Davoren GK, Montevecchi WA (2003a) Signals from seabirds indicate changing biology of capelin stocks. Mar Ecol Prog Ser 258:253-261

* Davoren GK, Montevecchi WA (2003b) Consequences of foraging trip duration on provisioning behavior and fledging condition of common murres Uria aalge. J Avian Biol 34:44-53

ํDiamond AW (1978) Feeding strategies and population size in tropical seabirds. Am Nat 112:215-223

* Dugger KM, Ballard G, Ainley DG, Barton KJ (2006) Effects of flipper bands on foraging behaviour and survival of Adélie penguins (Pygoscelis adeliae). Auk 123: 858-869

Dugger KM, Ainley DG, Lyver PO'B, Barton K, Ballard G (2010) Survival differences and the effect of environmental instability on breeding dispersal in an Adélie penguin meta-population. Proc Natl Acad Sci 107:12375-12380

* Dugger KM, Ballard G, Ainley DG, Lyver PO'B, Schine C (2014) Adélie penguins coping with environmental change: results from a natural experiment at the edge of their breeding range. Front Ecol Evol 2:68

*Eastman JT (1985) Pleuragramma antarcticum (Pisces, Nototheniidae) as food for other fishes in McMurdo Sound, Antarctica. Polar Biol 4:155-160

F Ford RG, Ainley DG, Lescroël A, Lyver PO'B, Toniolo V, Ballard G (2015) Testing assumptions of central place foraging theory: a study of Adélie penguins Pygoscelis adeliae in the Ross Sea. J Avian Biol 46:193-205

Forsman ED, Anthony RG, Dugger KM, Glenn EM and others (2011) Population demography of northern spotted owls. Studies in Avian Biology No. 40. Cooper Ornighological Society, Berkeley, CA

Furness RW, Birkhead TR (1984) Seabird colony distributions suggest competition for food supplies during the breeding season. Nature 311:655-656

Golet GH, Kuletz KJ, Roby DD, Irons DB (2000) Adult prey choice affects chick growth and reproductive success in pigeon guillemots. Auk 117:82-91

Gorman KB (2015) Integrative studies of southern ocean food-webs and Pygoscelis penguin demography: mechanisms of population response to environmental change. PhD dissertation, Simon Fraser University, Burnaby

Hinke JT, Salwicka K, Trivelpiece DG, Watters GM, Trivelpiece WZ (2007) Divergent responses of Pygoscelis pen- 
guins reveal a common environmental driver. Oecologia 153:845-855

Jennings S, Varsani A, Dugger KM, Ballard G, Ainley DG (2016) Sex-based differences in Adélie penguin (Pygoscelis adeliae) chick growth rates and diet. PLOS ONE 11:e0149090

Jones TM, Ward MP, Benson TJ, Brawn JD (2017) Variation in nestling body condition and wing development predict cause-specific mortality in fledgling dickcissels. J Avian Biol 48:439-447

La Mesa M, Eastman JT (2012) Antarctic silverfish: life strategies of a key species in the high-Antarctic ecosystem. Fish Fish 13:241-266

* La Mesa M, Catalano B, Russo A, Greco S, Vacchi M, Azzali $M$ (2010) Influence of environmental conditions on spatial distribution and abundance of early life stages of Antarctic silverfish, Pleuragramma antarcticum (Nototheniidae), in the Ross Sea. Antarct Sci 22:243-254

La Mesa M, Riginella E, Mazzoldi C, Ashford J (2015) Reproductive resilience of ice-dependent Antarctic silverfish in a rapidly changing system along the Western Antarctic Peninsula. Mar Ecol 36:235-245

Lack D (1968) Ecological adaptations for breeding in birds. Methuen, London

LaRue MA, Ainley DG, Swanson M, Dugger KM, Lyver PO, Barton K, Ballard G (2013) Climate change winners: receding ice fields facilitate colony expansion and altered dynamics in an Adélie penguin metapopulation. PLOS ONE 8:e60568

Lescroël A, Ballard G, Toniolo V, Barton KJ, Wilson PR, Lyver PO'B, Ainley DG (2010) Working less to gain more: when breeding quality relates to foraging efficiency. Ecology 91:2044-2055

Lynch HJ, LaRue ML (2014) First global census of the Adélie penguin. Auk 131:457-466

'Lyver PO'B, Barron M, Barton KJ, Ainley DG and others (2014) Trends in the breeding population of Adélie penguins in the Ross Sea, 1981-2012: a coincidence of climate and resource extraction effects. PLOS ONE 9: e91188

Kaness TJ, Anderson DJ (2013) Predictors of juvenile survival in birds. Ornithol Monogr 78:1-55

McClung MR, Seddon PJ, Massaro M, Setiawan AN (2004) Nature-based tourism impacts on yellow-eyed penguins Megadyptes antipodes: Does unregulated visitor access affect fledging weight and juvenile survival? Biol Conserv 119:279-285

Mougin JL, Jouanin C, Roux F, Zino F (2000) Fledging weight and juvenile survival of Cory's shearwaters Calonectris diomedea on Selvagem Grande. Ring Migr 20:107-110

Naef-Daenzer B, Grüebler MU (2016) Post-fledging survival of altricial birds: ecological determinants and adaptation. J Field Ornithol 87:227-250

Olsson O (1997) Effects of food availability on fledging condition and post-fledging survival in king penguin chicks. Polar Biol 18:161-165

Orians GH, Pearson NE (1979) On the theory of central place foraging. In: Horn DJ, Mitchell RD, Stairs GR (eds) Analysis of ecological systems. Ohio State University Press, Columbus, OH, p 154-177

* Perrig M, Grüebler MU, Keil H, Naef-Daenzer B (2017) Postfledging survival of little owls Athene noctua in relation to nestling food supply. Ibis 159:532-540

Perrins CM, Harris MP, Britton CK (1973) Survival of Manx shearwaters Puffinus puffinus. Ibis 115:535-548
R Core Team (2016) R: a language and environment for statistical computing. R Foundation for Statistical Computing, Vienna

Reilly PN, Cullen JM (1982) The little penguin Eudyptula minor in Victoria. III. Dispersal of chicks and survival after banding. Emu 82:137-142

* Remeš V, Matysioková B (2016) Survival to independence in relation to pre-fledging development and latitude in songbirds across the globe. J Avian Biol 47:610-618

Saenz BT, Ainley DG, Daly KL, Ballard G, Conlisk E, Elrod ML, Kim SL (2018) Trophic dynamics of the marginal ice zone in McMurdo Sound, Antarctica. PLOS ONE (in press)

Sagar PM, Horning DS Jr (1998) Mass-related survival of fledgling sooty shearwaters Puffinus griseus at The Snares, New Zealand. Ibis 140:329-339

Sailley SF, Ducklow HW, Moeller HV, Fraser WR and others (2013) Carbon fluxes and pelagic ecosystem dynamics near two western Antarctic Peninsula Adélie penguin colonies: an inverse model approach. Mar Ecol Prog Ser 492:253-272

Salihoglu B, Fraser WR, Hofmann EE (2001) Factors affecting fledging weight of Adélie penguin (Pygoscelis adeliae) chicks: a modelling study. Polar Biol 24:328-337

Saraux C, Viblanc VA, Hanuise N, Le Maho Y, Le Bohec C (2011) Effects of individual pre-fledging traits and environmental conditions on return patterns in juvenile king penguins. PLOS ONE 6:e20407

Schmutz JA (1993) Survival and pre-fledging body mass in juvenile emperor geese. Condor 95:222-225

* Schofield O, Ducklow HW, Martinson DG, Meredith MP, Moline MA, Fraser WR (2010) How do polar marine ecosystems respond to rapid climate change? Science 328: 1520-1523

Schreiber EA (2002) Climate and weather effects on seabirds. In: Schreiber EA, Burger J (eds) Biology of marine birds. CRC Press, Boca Raton, FL, p 179-216

Shealer DA (2002) Foraging behavior and food of seabirds. In: Schreiber EA. Burger J (eds) Biology of marine birds. CRC Press, Boca Raton, FL, p 137-178

Stammerjohn SE, Massom R, Rind D, Martinson DG (2012) Regions of rapid sea ice change: an inter-hemispheric seasonal comparison. Geophys Res Lett 39:L06501

Storer RW (1952) A comparison of variation, behavior and evolution in the seabird genera Uria and Cepphus. Univ Calif Publ Zool 52:121-222

Sutton CP, Horn PL (2011) A preliminary assessment of age and growth of Antarctic silverfish (Pleuragramma antarcticum) in the Ross Sea, Antarctica. CCAMLR Sci 18: 75-86

Taylor RH, Roberts HS (1962) Growth of Adélie penguin (Pygoscelis adeliae Hombron and Jacquinot) chicks. N Z J Sci 5:191-197

* Tveraa T, Saether BE, Aanes R, Erikstad KE (1998) Regulation of food provisioning in the Antarctic petrel; the importance of parental body condition and chick body mass. J Anim Ecol 67:699-704

Vitz AC, Rodewald AD (2011) Influence of condition and habitat use on survival of post-fledging songbirds. Condor 113:400-411

Volkman NJ, Trivelpiece WZ (1980) Growth of pygoscelid penguin chicks. J Zool 191:521-530

Wakefield ED, Bodey TW, Bearhop S, Blackburn J and others (2013) Space partitioning without territoriality in gannets. Science 341:68-70

Waluda CM, Hill SL, Peat HJ, Trathan PN (2012) Diet 
variability and reproductive performance of macaroni penguins Eudyptes chrysolophus at Bird Island, South Georgia. Mar Ecol Prog Ser 466:261-274

Weller F, Cecchini LA, Shannon L, Sherley RB and others (2014) A system dynamics approach to modelling multiple drivers of the African penguin population on Robben Island, South Africa. Ecol Modell 277:38-56

Wendeln H, Becker PH (1999) Effects of parental quality and effort on the reproduction of common terns. J Anim Ecol 68:205-214

Whitehead AL, Lyver PO, Ballard G, Barton K and others
(2015) Factors driving Adélie penguin chick size, mass and condition at colonies of different sizes in the Southern Ross Sea. Mar Ecol Prog Ser 523:199-213

Williams TD, Croxall JP (1991) Chick growth and survival in gentoo penguins (Pygoscelis papua): effect of hatching asynchrony and variation in food supply. Polar Biol 11: 197-202

* Ydenberg RC, Welham CVJ, Schmid-Hempel R, SchmidHempel P, Beauchamp G (1994) Time and energy constraints and the relationships between currencies in foraging theory. Behav Ecol 5:28-34

\section{Appendix}

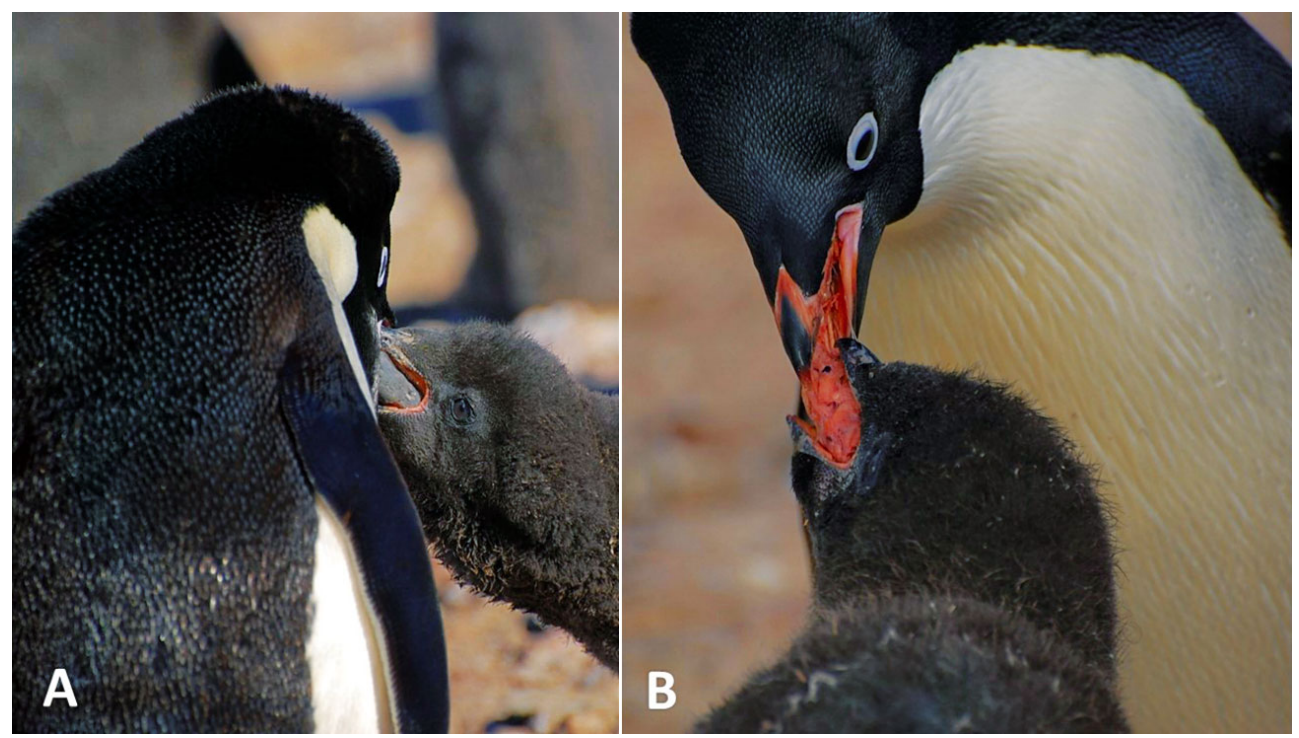

Fig. A1. A major part of our effort involved observing the color and texture of food passing from parent to chick. (A) Gray food represented silverfish and (B) pink represented crystal krill. Images by Jean Pennycook, Cape Royds, Ross Island, 2017

Editorial responsibility: Kyle Elliott, Sainte-Anne-de-Bellevue, Québec, Canada
Submitted: April 23, 2018; Accepted: July 2, 2018

Proofs received from author(s): August 3, 2018 